\title{
Wpływ wieku osoby badanej na wyniki rozdzielnousznego testu liczbowego
}

\section{The effect of age of a subject on the results of the Dichotic Digit Test}

\author{
Karolina Dajos-Krawczyńska ${ }^{1}$, Krzysztof Kochanek $^{1}$, Adam Piłka ${ }^{1}$, Katarzyna Biegun ${ }^{1,2}$, \\ Justyna Jasińska ${ }^{1,2}$, Henryk Skarżyński ${ }^{1}$ \\ ${ }^{1}$ Instytut Fizjologii i Patologii Słuchu, Światowe Centrum Słuchu, Warszawa/Kajetany \\ ${ }^{2}$ UMCS, Zakład Logopedii i Językoznawstwa, Lublin
}

Adres autora: Karolina Dajos-Krawczyńska, Światowe Centrum Słuchu, ul. Mokra 17, Kajetany, 05-830 Nadarzyn, e-mail: k.dajos@ifps.org.pl

\section{Streszczenie}

Wstęp: Testy słyszenia rozdzielnousznego pozwalają na ocenę integracji i separacji słuchowej, pamięci krótkotrwałej, podzielności i selektywności uwagi. Słyszenie rozdzielnouszne jest także uważane za wskaźnik lateralizacji półkulowej w zakresie bodźców werbalnych i niewerbalnych. Testy rozdzielnouszne są powszechnie używane w diagnozie zaburzeń przetwarzania słuchowego. Celem pracy była ocena wpływu wieku na wyniki testu rozdzielnousznego liczbowego (DDT).

\begin{abstract}
Materiał i metody: Badaniami objęto trzy grupy dzieci w wieku 5 (n=19), 7 (n=21) oraz 12 lat (n=23) o prawidłowej czułości słuchu. Test rozdzielnouszny liczbowy wykonano za pomocą oprogramowania komputerowego APD. W każdej grupie wiekowej test rozdzielnouszny liczbowy (DDT) wykonano trzykrotnie.
\end{abstract}

Wyniki: Wiek w sposób istotny wpływa na wyniki testu DDT. Dzieci 5-letnie uzyskują istotnie statystycznie słabsze wyniki w porównaniu z dziećmi w wieku 7 i 12 lat. W grupie dzieci starszych rozrzut wyników był znacznie mniejszy niż w grupach dzieci młodszych. Analiza wyników indywidualnych nie wykazała występowania istotnych różnic pomiędzy kolejnymi pomiarami, niezależnie od odsetka prawidłowych odpowiedzi. Nie wykazano również tendencji do poprawy wyników w kolejnych badaniach.

Wnioski: Podczas analizy i interpretacji wyników testu rozdzielnousznego cyfrowego należy brać pod uwagę czynniki, które mogą wpływać na uzyskane wyniki, między innymi wiek i badane ucho. Badania w grupie dzieci starszych odznaczają się większą wiarygodnością i stabilnością.

Słowa kluczowe: zaburzenia przetwarzania słuchowego • test rozdzielnouszny liczbowy • test rozdzielnousznego słyszenia

Abstract

Objective: Dichotic listening tests allow to evaluate auditory integration and separation abilities, short-term memory, selective attention and divided attention. Dichotic listening is also considered as an indicator of hemispheric lateralization of verbal and nonverbal stimuli. Dichotic tests are commonly used in diagnosis of central auditory processing disorders. The aim of this study was to assess the effects of age on the results of the Dichotic Digit Test (DDT).

Material and methods: The study included three groups of children aged $5(n=19), 7(n=21)$ and 12 years $(n=23)$ with normal hearing sensitivity. Dichotic digit test was performed using computer software APD. In each age group the Dichotic Digit Test (DDT) was done three times.

Results: Age has a significant impact on the results of the dichotic digit test. 5 years old children obtain significantly poorer results compared with children aged 7 and 12 years. In the group of older children scatter of results was much smaller than in the group of younger children. Analysis of the results showed no individual marked differences between three successive measurements, regardless of the percentage of correct answers. There was no trend for improvement in three subsequent measurements. 
Conclusions: During the analysis and interpretation of the results of the Dichotic Digit Test specialists should take into consideration factors that may affect the results, including age and studied ear. Research in the group of older children are more reliable and stable.

Key words: Central Auditory Diseases $•$ DDT • Dichotic Listening Tests

\section{Wprowadzenie}

Testy rozdzielnouszne są powszechnie używane w badaniach eksperymentalnych i klinicznych ośrodkowego układu słuchowego. Pozwalają na ocenę integracji i separacji słuchowej, asymetrii międzyusznej, uwagi słuchowej, szybkości przetwarzania bodźców, a także na określenie półkuli dominującej w zakresie przetwarzania mowy i języka $[1,2]$.

Technika słyszenia rozdzielnousznego to eksperymentalna procedura $\mathrm{z}$ dziedziny neuropsychologii, opracowana we wczesnych latach 60 . XX w., w celu badania funkcjonalnej, słuchowej lateralizacji korowej. Określenie „rozdzielnouszne” odnosi się do sposobu prezentowania bodźca: dwa różne bodźce są podawane jednocześnie jeden do prawego i jeden do lewego ucha [3]. W badaniu mogą być stosowane bodźce werbalne (sylaby, słowa, cyfry, zdania) oraz niewerbalne (tony, melodie, bodźce o nacechowaniu emocjonalnym). Specjalizacja poszczególnych półkul mózgowych powoduje powstawanie asymetrii słuchowej [4] - zastosowanie bodźców słownych powoduje zwykle powstanie zjawiska tzw. przewagi ucha prawego (więcej prawidłowych odpowiedzi dla bodźców docierających do ucha prawego), z kolei użycie bodźców niewerbalnych powoduje powstanie przewagi ucha lewego [5]. Powstawanie przewagi ucha prawego w badaniach z użyciem bodźców językowych związane jest z budową i właściwościami układu słuchowego (m.in. bezpośrednie połączenie ucha kontralateralnego z obszarami lewej półkuli dominującej dla mowy, supresja bodźców ipsilateralnych przez bodźce kontralateralne, wydłużony czas transferu pobudzeń z ucha ipsilateralnego do półkuli dominującej) [6], jak również z procesami uwagi [7]. Badania elektrofizjologiczne [8] i neuroobrazowe [5,9-11] potwierdzają anatomiczną i poznawczą teorię istnienia przewagi ucha prawego. Badania korowych potencjałów elektrycznych wywołanych bodźcami słownymi przeprowadzone przez Sobótkę i Grodzicką [1989] również wskazują na przewagę ucha prawego podczas przetwarzania bodźców werbalnych [12].

Jednym z najważniejszych czynników, które wywierają istotny wpływ na wyniki testów rozdzielnousznych, jest wiek. Liczne badania wykazały, że wraz z wiekiem znacznie zwiększa się odsetek prawidłowych odpowiedzi. Starsze dzieci osiągają znacznie lepsze wyniki niż dzieci młodsze, a w wieku około 12 lat mają wyniki zbliżone do wyników osób dorosłych [13-16]. Jest to prawdopodobnie spowodowane dojrzewaniem i mielinizacją ipsilateralnych i kontralateralnych włókien drogi słuchowej oraz ciała modzelowatego, co powoduje nabywanie zdolności szybkiego przetwarzania bodźców oraz zwiększenie efektywności transferu pomiędzy półkulami mózgowymi [17].

Wiek w istotny sposób wpływa również na kierunek lateralizacji i stopień przewagi ucha. Jak wskazuje Mroziak [1992], lateralizacja jest to przewaga stronna, która dotyczy zarówno funkcji parzystych organów ciała, jak i funkcji psychicznych [4], a więc także słuchu. Nie jest pewne, kiedy kształtuje się lateralizacja słuchowa. Część badań u niemowląt i małych dzieci wskazuje, że już w okresie niemowlęcym rowzija się asymetria półkulowa w zakresie bodźców językowych [18]. Hipotezę tę potwierdzają wyniki funkcjonalnego rezonansu magnetycznego fMRI [19] oraz magnetoelektoencefalografii - MEG [20]. Badania Kimury [6] i Berlina [15] z użyciem procedury słyszenia rozdzielnousznego wykazują istnienie przewagi ucha prawego, wskazującej na dominację lewej półkuli mózgu w zakresie przetwarzania bodźców werbalnych u dzieci w wieku 4-5 lat. Badania neuroobrazowe również potwierdzają dominującą aktywację lewej półkuli mózgu u dzieci 5-10-letnich w czasie przetwarzania bodźców językowych [21-23]. Z kolei Bryden [24] wskazuje, że wielkość przewagi ucha prawego u dzieci praworęcznych jest zmienna w okresie pomiędzy 2 a 6 rokiem życia, sugerując, że lateralizacja językowa u młodszych dzieci nie jest w pełni wykształcona. Bryden [24] wykazał również, że u niektórych dzieci leworęcznych około 6 roku życia następuje zmiana przewagi ucha w kierunku ucha lewego, co pozwala przypuszczać, że kierunek przewagi ucha może podlegać zmianom rozwojowym.

Niezależnie od tego, kiedy następuje ukształtowanie lateralizacji półkulowej w zakresie języka, u około 95\% osób praworęcznych i $70 \%$ osób leworęcznych półkulą dominującą w zakresie przetwarzania bodźców słownych jest półkula lewa $[25,26]$, co znajduje odzwierciedlenie w zjawisku przewagi ucha prawego $\mathrm{w}$ badaniach rozdzielnousznych $\mathrm{z}$ użyciem bodźców werbalnych. U dzieci młodszych różnica pomiędzy wynikami w uchu prawym i lewym jest znacznie większa niż u dzieci starszych [2]. Wraz z wiekiem zwiększa się zdolność układu słuchowego do percepcji, przetwarzania i interpretacji bodźców akustycznych, co skutkuje zwiększeniem liczby prawidłowych odpowiedzi dla bodźców docierających z obojga uszu. Wzrost liczby prawidłowych odpowiedzi w uchu lewym jest większy niż w uchu prawym, co powoduje zmniejszenie wielkości przewagi ucha prawego [2].

Uwaga jest kolejnym czynnikiem, który odgrywa istotną rolę $\mathrm{w}$ czasie badania integracji i separacji słuchowej oraz jest źródłem zmienności wyników w testach rozdzielnousznych [24]. Liczne badania wykazały, że po ukierunkowaniu uwagi na jedno z uszu następuje zwiększenie liczby prawidłowych odpowiedzi dla bodźców docierających z tego ucha i jednocześnie zmniejszenie liczby poprawnych odpowiedzi z ucha przeciwnego [27]. Po ukierunkowaniu uwagi na ucho prawe znacznie zwiększa się przewaga ucha prawego, co jest skutkiem niewielkiego przyrostu liczby prawidłowych odpowiedzi z ucha prawego i znacznego zmniejszenia odpowiedzi $z$ ucha lewego. Natomiast w przypadku uwagi ukierunkowanej na ucho lewe obserwuje się wzrost liczby prawidłowych odpowiedzi w uchu lewym i zmniejszenie przewagi ucha prawego lub nawet powstanie przewagi ucha lewego [28]. 

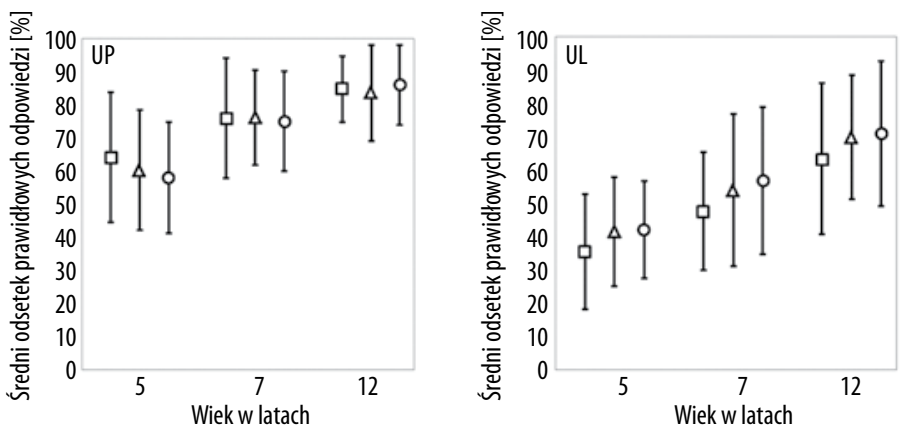

Rycina 1. Średni odsetek prawidłowo powtórzonych liczb $w$ trzech kolejnych pomiarach uwagi rozproszonej $w$ zależności od grupy wiekowej ( $\square-1$ pomiar, $\triangle-2$ pomiar, $\bigcirc-3$ pomiar)

Figure 1. Mean percentage of correctly repeated numbers in three consecutive measurements in divided attention depending on the age group ( $\square-1^{\text {st }}$ measurement, $\triangle-2^{\text {nd }}$ measurement, $\mathrm{O}-3^{\text {rd }}$ measurement)
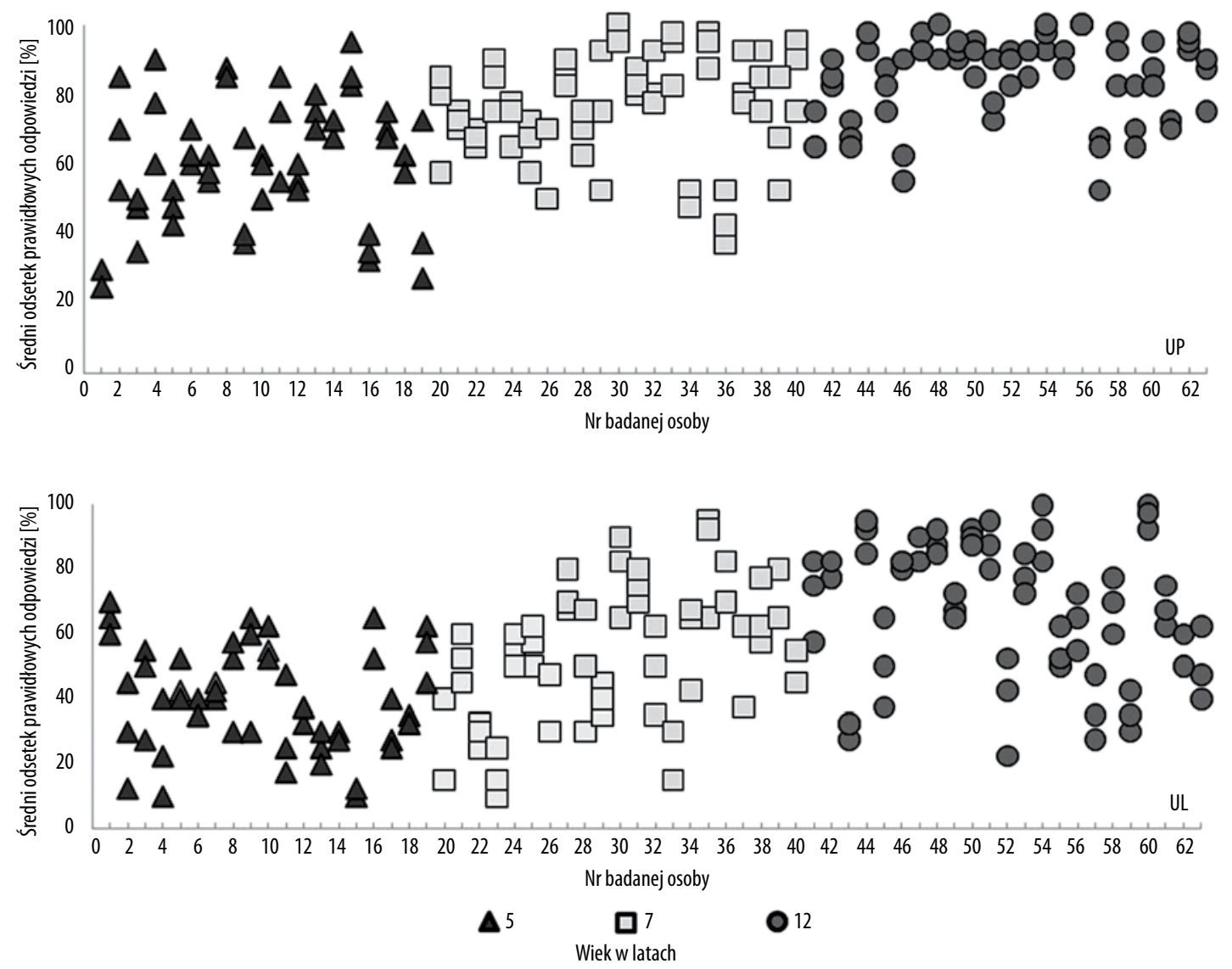

Rycina 2. Indywidualne wyniki testu uwagi rozproszonej w trzech grupach wiekowych

Figure 2. Individual divided attention test results in three age groups

Badania różnych autorów wykazały, że testy słyszenia rozdzielnousznego z użyciem cyfr wykazują dużą czułość na uszkodzenia ośrodkowych struktur drogi słuchowej [17,29]. Z tego powodu często stosowane są w diagnozie zaburzeń przetwarzania słuchowego (ang. Auditory Processing Disorders, APD). Zaburzenia w zakresie słuchania rozdzielnousznego występują nawet u $65,5 \%$ dzieci z grupy ryzyka APD [30]. Dzieci z ośrodkowymi zaburzeniami słuchu osiągają słabsze wyniki w testach rozdzielnousznych niż ich rówieśnicy z grup kontrolnych [14,31]. Zaburzenia integracji i separacji słuchowej mogą powodować trudności m.in. w rozumieniu mowy w hałasie, rozumieniu złożonych instrukcji i poleceń, rozumieniu tekstów dyktowanych, problemy w czytaniu i pisaniu, trudności ze skupieniem uwagi w czasie dłuższego słuchania [32].

Pomimo powszechnego stosowania testu DDT w pracowniach audiologicznych i logopedycznych, nie opracowano dotąd jednolitych kryteriów oceny poprawności wyniku oraz nie poznano w wystarczający sposób zmienności wyników tego testu w zależności od wieku.

Celem pracy była ocena wpływu wieku na wyniki rozdzielnousznego testu liczbowego. Dodatkowo analizowano wielkość rozrzutu śród- i międzyosobniczego rezultatów testów w funkcji wieku oraz czas wykonywania 

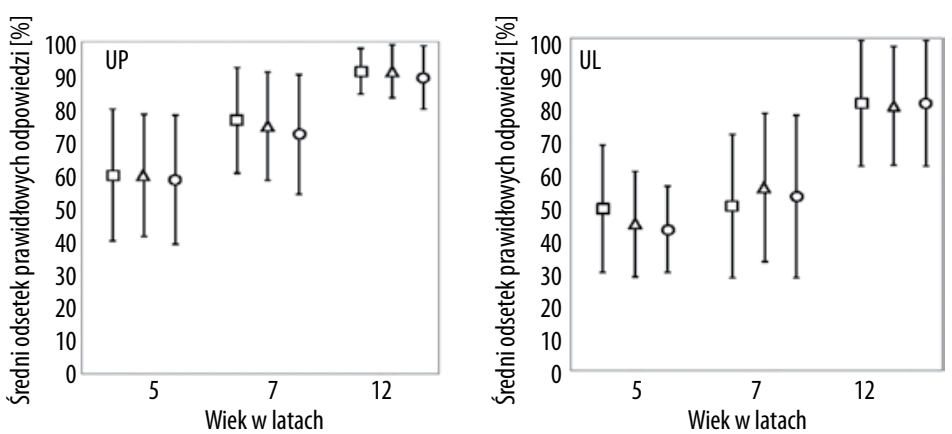

Rycina 3. Średni odsetek prawidłowo powtórzonych liczb $w$ trzech kolejnych pomiarach uwagi ukierunkowanej w zależności od grupy wiekowej ( $\square-1$ pomiar, $\triangle-2$ pomiar, $\bigcirc-3$ pomiar)

Figure 3. Mean percentage of correctly repeated numbers in three consecutive measurements in focused attention depending on the age group ( $\square-1^{\text {st }}$ measurement, $\triangle-2^{\text {nd }}$ measurement, $\mathrm{O}-3^{\text {rd }}$ measurement) poszczególnych testów w celu oceny stopnia trudności testu w poszczególnych grupach wiekowych.

\section{Materiał i metoda}

Badaniami objęto grupę 63 dzieci w wieku $5(\mathrm{n}=19)$, $7(n=21)$ oraz 12 lat $(n=23)$. Wszystkie dzieci zakwalifikowane do badania miały prawidłową czułość słuchu w zakresie częstotliwości 250-8000 Hz (progi $\leq 20 \mathrm{~dB} \mathrm{HL).}$ Dobór grup badawczych podyktowany był sytuacją edukacyjną dzieci - grupa 5-latków kończy naukę w przedszkolu i przygotowuje się do rozpoczęcia nauki w zerówce lub w szkole podstawowej, dzieci 7-letnie rozpoczęły w szkole naukę czytania i pisania, natomiast 12-latki kończą edukację w szkole podstawowej i przygotowują się do dalszej nauki w gimnazjum. Wśród dzieci zakwalifikowanych do badania 12 było leworęcznych ( $3 \mathrm{w}$ grupie 5-latków, 5 w grupie 7-latków oraz 4 w grupie 12-latków).

Rozdzielnouszny test liczbowy wykonano za pomocą programu komputerowego APD, opracowanego w Instytucie Fizjologii i Patologii Słuchu, zainstalowanego na komputerze przenośnym wyposażonym w słuchawki nauszne Sennheiser HDA 200 [33]. U każdego dziecka rozdzielnouszny test liczbowy wykonano z użyciem dwóch protokołów - uwagi rozproszonej oraz ukierunkowanej na prawe i lewe ucho. Podczas badania prezentowano jednocześnie do obojga uszu dwie różne pary liczb (dwie liczby do ucha lewego i dwie liczby do ucha prawego). Bodźce podawano $\mathrm{z}$ natężeniem $60 \mathrm{~dB}$ HL. W przypadku badania integracji słuchowej (uwaga rozproszona) zadaniem dziecka było powtórzenie wszystkich usłyszanych liczb, natomiast w przypadku badania separacji słuchowej (uwaga ukierunkowana) powtórzenie cyfr usłyszanych tylko w prawym bądź lewym uchu. Wynikiem badania był odsetek prawidłowo powtórzonych liczb, usłyszanych w każdym uchu.

W celu oceny wiarygodności i powtarzalności wyników badań u każdego dziecka pomiar wykonano trzykrotnie. Odstęp pomiędzy pierwszym i drugim badaniem wynosił 1 dzień, natomiast między drugim i trzecim od 1 do 2 tygodni.

Wyniki badań poddano analizie statystycznej za pomocą programu STATISTICA z użyciem testu jednowymiarowej analizy wariancji ANOVA. Za istotne uznawano wartości $\mathrm{p}<0,05$. Głównym celem analizy była ocena, czy wiek w sposób istotny wpływa na wyniki rozdzielnousznego testu liczbowego. W celu oceny trudności zadania analizie poddano również czas wykonywania testu w poszczególnych grupach wiekowych.

\section{Wyniki}

Nie wykazano istotnego wpływu płci na wyniki rozdzielnousznego testu liczbowego ( $p>0,05)$, niezależnie od grupy wiekowej. Zarówno w grupie młodszych, jak i starszych dzieci chłopcy i dziewczynki osiągali zbliżone wyniki.

Analiza statystyczna nie wykazała również istnienia korelacji pomiędzy lateralizacją ręki a lateralizacją słuchową. Dzieci wykazujące dominację lewej ręki, podobnie jak dzieci praworęczne, w teście rozdzielnousznym osiągały istotnie lepsze wyniki dla ucha prawego.

Na rycinie 1. przedstawiono średni odsetek prawidłowych odpowiedzi uzyskanych w trzech kolejnych pomiarach uwagi rozproszonej $\mathrm{w}$ uchu prawym i lewym w grupie 5-, 7- i 12-latków. Zarówno w uchu prawym, jak i lewym dzieci 12-letnie osiągnęły znacznie większy odsetek prawidłowych odpowiedzi niż dzieci 7- i 5-letnie $(p<0,05)$. Średni odsetek prawidłowych odpowiedzi w grupie dzieci najmłodszych wynosił ok. $60 \% \mathrm{w}$ uchu prawym i $40 \%$ w uchu lewym, w grupie 7-latków około $75 \%$ w uchu prawym i 52\% w uchu lewym, natomiast w grupie dzieci najstarszych ok. $85 \%$ w uchu prawym i $70 \%$ w uchu lewym.

Niezależnie od grupy wiekowej, większy odsetek prawidłowych odpowiedzi uzyskano w badaniu ucha prawego $(\mathrm{p}<0,05)$, w którym obserwowano zmniejszenie wartości odchylenia standardowego wraz z wiekiem. Natomiast w uchu lewym we wszystkich grupach wiekowych odchylenie standardowe miało zbliżoną wartość (rycina 1).

Analizie poddano indywidualne wyniki testu DDT z trzech kolejnych pomiarów uwagi rozproszonej (rycina 2). $\mathrm{W}$ przypadku ucha prawego wraz $\mathrm{z}$ wiekiem zmniejsza się wielkość rozrzutu międzyosobniczego i śródosobniczego wyników, co świadczy o tym, że w grupach dzieci starszych badania ucha prawego odznaczają się większą wiarygodnością i powtarzalnością. W przypadku ucha lewego we wszystkich grupach wiekowych wielkość rozrzutu wyników była zbliżona.

W badaniach uwagi ukierunkowanej, podobnie jak w przypadku uwagi rozproszonej, średni odsetek prawidłowych odpowiedzi w obojgu uszach zwiększał się wraz z wiekiem (rycina 3). W uchu prawym dzieci 5-letnie osiągają około $60 \%$ poprawnych odpowiedzi, dzieci 7-letnie około 75\%, natomiast dzieci 12-letnie ponad 90\%. Z kolei w uchu lewym najmłodsze dzieci udzielają średnio około $45 \%$ prawidłowych odpowiedzi, 7-latki około 55\%, zaś dzieci najstarsze około $80 \%$. 

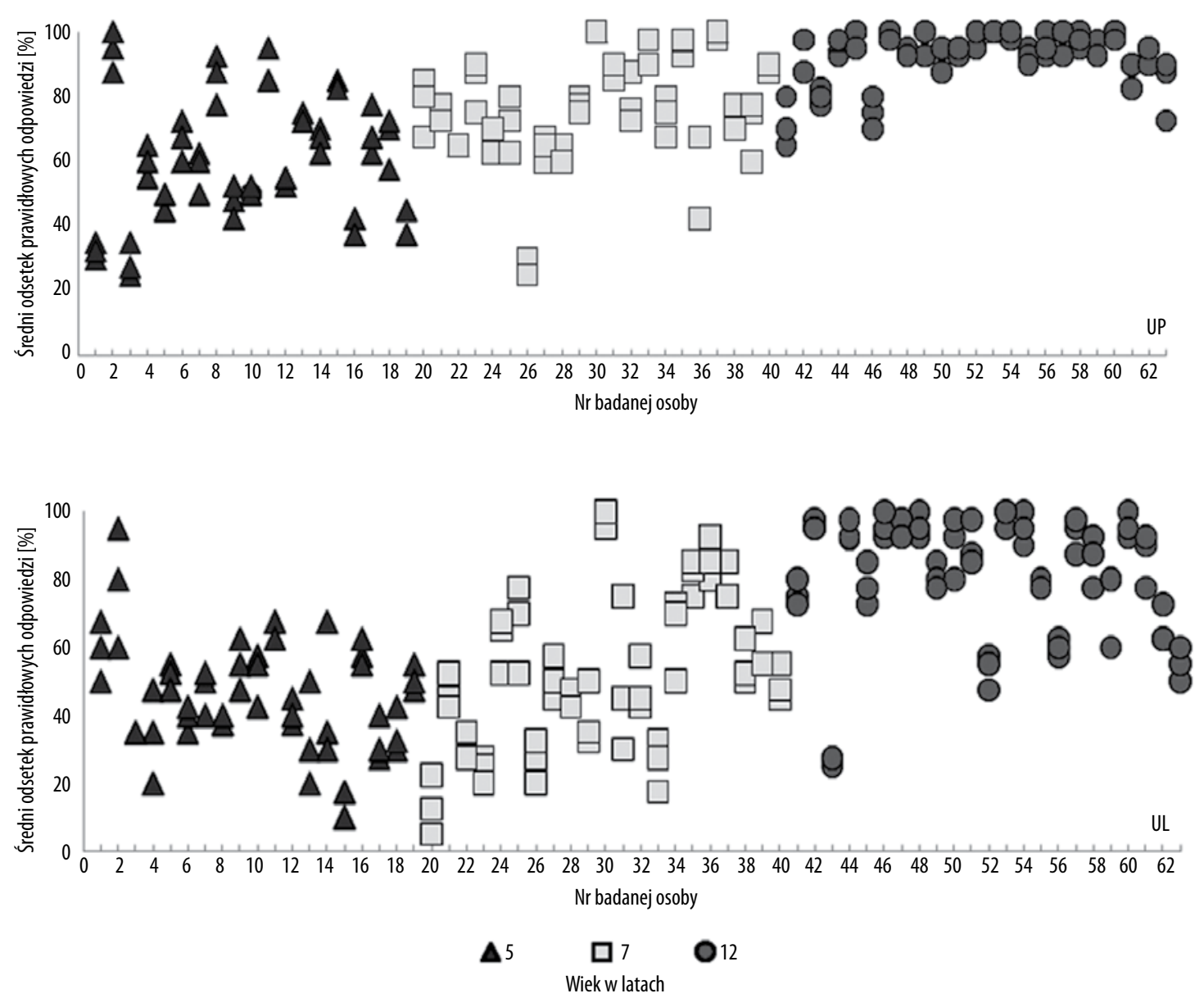

Rycina 4. Indywidualne wyniki badania uwagi ukierunkowanej w trzech grupach wiekowych

Figure 4. Individual focused attention test results in three age groups

We wszystkich grupach wiekowych większy odsetek prawidłowych odpowiedzi uzyskano w uchu prawym $(\mathrm{p}<0,05)$. $\mathrm{W}$ uchu prawym wraz $\mathrm{z}$ wiekiem zmniejsza się również wielkość odchylenia standardowego, natomiast w uchu lewym we wszystkich grupach wiekowych odchylenie standardowe ma zbliżoną wartość (rycina 3).

Na rycinie 4. przedstawiono indywidualne wyniki testu DDT w badaniu uwagi ukierunkowanej w uchu prawym i lewym. W badaniu uwagi ukierunkowanej na ucho prawe w grupie dzieci 12-letnich zaobserwowano niewielki rozrzut międzyi śródosobniczy wyników. Jak wynika $z$ analizy indywidualnych wyników badania, dzieci 7- i 5-letnie odznaczają się większym rozrzutem wyników. W uchu lewym we wszystkich grupach wiekowych, niezależnie od odsetka prawidłowych odpowiedzi, rozrzut wyników jest zbliżony (rycina 4).

Jednoczesna rejestracja odpowiedzi z prawego i lewego ucha podczas badania uwagi rozproszonej pozwala na ocenę asymetrii międzyusznej, czyli różnicy pomiędzy wynikami uzyskiwanymi w obojgu uszach. Dlatego wyznaczono średnie bezwzględne wartości różnic pomiędzy wynikami ucha prawego i lewego. Zgodnie z oczekiwaniami, w grupie dzieci 5-letnich występują największe różnice pomiędzy wynikami obojga uszu. Wielkość asymetrii słuchowej zmniejsza się wraz z wiekiem, jednak różnica pomiędzy grupami wiekowymi nie była istotna statystycznie (rycina 5).

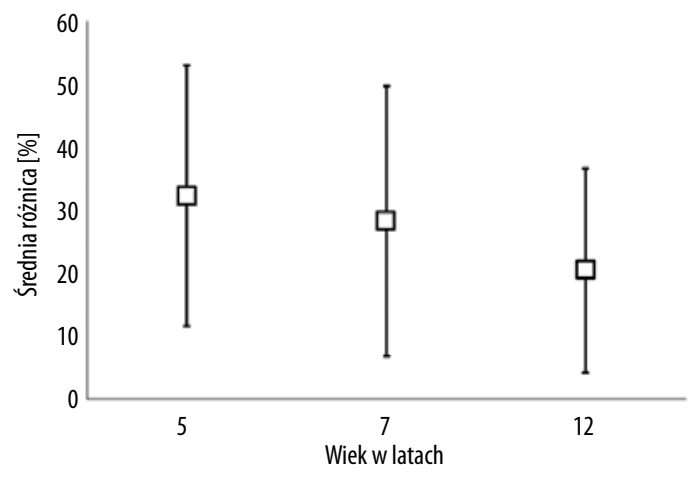

Rycina 5. Średnie bezwzględne wartości różnicy pomiędzy wynikiem prawego i lewego ucha w badaniu uwagi rozproszonej w trzech grupach wiekowych

Figure 5. Mean absolute values of difference between the results in the right and left ear in the divided attention tests in three age group

Dodatkowo poddano analizie czas wykonania poszczególnych testów. Na rycinie 6. przedstawiono średni czas trwania badania uwagi rozproszonej oraz uwagi ukierunkowanej na ucho prawe i lewe. We wszystkich próbach czas wykonania badania był najkrótszy w grupie dzieci 12-letnich, natomiast najdłuższy w grupie dzieci 5-letnich. 

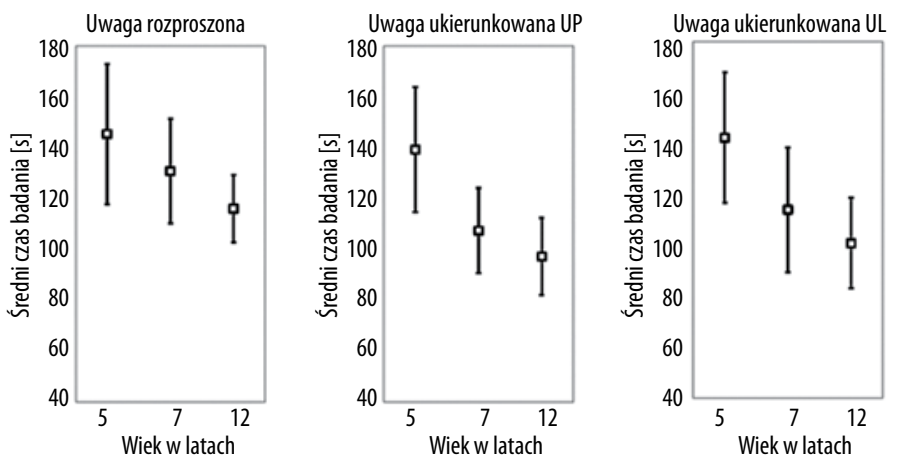

Rycina 6. Średni czas trwania badania $w$ trzech kolejnych pomiarach uwagi rozproszonej i ukierunkowanej w zależności od grupy wiekowej

Figure 6. Mean time of the divided and focused attention tests in three consecutive measurements depending on the age group

Badanie uwagi rozproszonej we wszystkich grupach wiekowych trwało nieco dłużej niż badanie uwagi ukierunkowanej. Najkrótsze czasy trwania badania wyznaczono dla badania uwagi ukierunkowanej na ucho prawe (rycina 6). Różnice pomiędzy grupami nie były istotne statystycznie $(p>0,05)$.

\section{Dyskusja}

W celu określenia norm dla poszczególnych testów funkcji słuchowych niezbędne jest zbadanie, czy na wyniki danego testu mają wpływ czynniki związane zarówno z samym testem (np. rodzaj zastosowanego bodźca, parametry bodźca), procedurą badania (instrukcja, sposób sygnalizowania odpowiedzi, rejestracja odpowiedzi), jak i czynniki osobnicze związane $\mathrm{z}$ uczestnikami badania (wiek, płeć, badane ucho).

Jednym z najistotniejszych czynników, które mają wpływ na wyniki testów rozdzielnousznych, jest wiek. Większość testów ośrodkowych funkcji słuchowych przeznaczona jest dla dzieci powyżej 6-7 roku życia, ponieważ, jak wskazują liczne badania, rozwój funkcji słuchowych trwa nawet do 10-12 roku życia. W tym czasie następuje dojrzewanie i mielinizacja włókien nerwowych łączących poszczególne elementy układu słuchowego. W przypadku testów rozdzielnousznych duże znaczenie ma rozwój struktur ciała modzelowatego. Badania wskazują, że dojrzewanie włókien ciała modzelowatego, które mają istotne znaczenie $\mathrm{w}$ transferze informacji pomiędzy półkulami mózgowymi, trwa nawet do około 20 roku życia [17].

W niniejszej pracy badaniom poddano m.in. dzieci w wieku 5 lat. Nieliczne badania w tej grupie wiekowej nie są jednoznaczne i odznaczają się dużą zmiennością. Ingram [34] sugeruje, że przewaga ucha prawego jest obecna u dzieci już w wieku ok. 3 lat. Kimura [6] i Berlin [15] wskazują, że u dzieci w tym wieku obserwuje się znaczne asymetrie międzyuszne, $\mathrm{z}$ wyraźną przewagą ucha prawego. Istnienie asymetrii pomiędzy prawym i lewym uchem w zakresie bodźców językowych potwierdzają badania Chi i wsp. [18], a także badania za pomocą fMRI [19] i MEG [20], prowadzone w grupie niemowląt i małych dzieci. Wyniki te sugerują, że już w tym wieku wykształca się dominacja lewej półkuli mózgu w przetwarzaniu bodźców językowych. Z kolei Bryden [24] sugeruje, że lateralizacja językowa u młodszych dzieci może podlegać zmianom rozwojowym. W niniejszej pracy zaobserwowano w tej grupie wiekowej duży rozrzut międzyosobniczy wyników. Wysoki odsetek prawidłowych odpowiedzi uzyskany przez niektóre dzieci wskazuje, że u części 5-latków lateralizacja półkulowa w zakresie bodźców językowych jest już ukształtowana, natomiast $\mathrm{u}$ innych dzieci proces ten jeszcze trwa. Niezależnie jednak od odsetka prawidłowych odpowiedzi, badania wykazały, że wyniki w tej grupie wiekowej są powtarzalne i wiarygodne, o czym świadczy niezbyt duży rozrzut indywidualnych wyników badań w trzech próbach.

Wraz z wiekiem zwiększa się liczba prawidłowych odpowiedzi - starsze dzieci osiągają znacznie lepsze wyniki niż dzieci młodsze. Wyniki młodszych dzieci charakteryzują się również większą zmiennością, o czym świadczy większy rozrzut indywidualnych wyników oraz większe odchylenie standardowe średnich wartości odsetka prawidłowych odpowiedzi. W niniejszej pracy wykazano, że średni odsetek prawidłowo powtórzonych liczb w grupie dzieci 12-letnich był znacznie wyższy niż średni odsetek uzyskany przez dzieci 7- i 5-letnie $(\mathrm{p}<0,05)$. Uzyskane wyniki są zbliżone do wyników innych autorów [13,15,35,36], w których wykazano istotny wpływ wieku na uzyskiwane wyniki testów rozdzielnousznych. Podobnie jak w niniejszej pracy, młodsze dzieci osiągały słabsze wyniki niż dzieci starsze. Lamm i wsp. [37] badali dwukrotnie tę samą grupę dzieci za pomocą testów rozdzielnousznych z zastosowaniem bodźców liczbowych i słownych. Po upływie jednego roku w obu testach dzieci osiągnęły znacznie lepsze wyniki w obojgu uszach, zmniejszyła się również wielkość różnicy pomiędzy wynikami lewego i prawego ucha. Badania wskazują, że dopiero w wieku 11-12 lat dzieci osiągają wyniki zbliżone do osób dorosłych [2,35]. W badaniach Moncrieff [2] $\mathrm{w}$ rozdzielnousznym teście liczbowym $\mathrm{z}$ użyciem dwóch par cyfr dzieci w wieku 10-11 lat oraz 12-14 lat osiągnęły w uchu prawym wyniki podobne do osób dorosłych (ok. 93\% dzieci oraz ok. 98\% dorośli), a w uchu lewym tylko nieznacznie niższe niż dorośli (ok. 85\%, dorośli 97,\%).

W niniejszej pracy we wszystkich grupach wiekowych, zarówno w badaniu uwagi rozproszonej, jak i ukierunkowanej, wykazano istotnie wyższy odsetek prawidłowych odpowiedzi w uchu prawym. Wyraźna przewaga ucha prawego wskazuje na dominację lewej półkuli mózgu dla bodźców werbalnych. Przewagę ucha prawego w badaniach rozdzielnousznych z użyciem bodźców werbalnych wykazali także Vanniasegaram i wsp. [14], Berlin [15], Mukari i wsp. [35], Moncrieff i wsp. [36], Romero-Diaz i wsp. [39]. Dominującą aktywację lewej półkuli mózgu u dzieci 5-10-letnich w czasie przetwarzania bodźców językowych potwierdzają również badania neuroobrazowe [21-23,40]. 
Przewaga ucha prawego związana jest $\mathrm{z}$ występowaniem asymetrii międzyusznych. W niniejszej pracy u młodszych dzieci zaobserwowano większe różnice pomiędzy wynikami uzyskiwanymi w prawym i lewym uchu niż u dzieci starszych. Zenker i wsp. [13] w liczbowym teście rozdzielnousznym wykazali występowanie znacznych różnic pomiędzy wynikami z obojga uszu u dzieci w wieku 6-12 lat. Wraz z wiekiem stopniowo zmniejsza się wielkość asymetrii międzyusznej, co skutkuje znacznym zwiększeniem odsetka prawidłowych odpowiedzi z ucha lewego i tylko niewielkim wzrostem odsetka prawidłowych odpowiedzi z ucha prawego. Mukari i wsp. [35] badali dzieci w wieku 6-11 lat. Zaobserwowali oni, że wraz z wiekiem wyniki zarówno $\mathrm{z}$ ucha prawego, jak i lewego ulegają poprawie we wszystkich grupach wiekowych, przy czym wzrost liczby prawidłowych odpowiedzi z ucha lewego jest większy w porównaniu ze wzrostem liczby prawidłowych odpowiedzi z ucha prawego. Co ciekawe, zaobserwowali oni występowanie wyraźnych asymetrii międzyusznych w badaniach uwagi rozproszonej i ukierunkowanej na ucho prawe, natomiast $\mathrm{w}$ przypadku ukierunkowania uwagi na ucho lewe wyraźne asymetrie międzyuszne występowały tylko u młodszych dzieci - w wieku 6, 7 i 8 lat. Około 8-9 roku życia dzieci nabywają zdolność „przezwyciężenia” przewagi ucha prawego po ukierunkowaniu uwagi na ucho lewe [34]. Hiscock i wsp. [41] wykazali, że dzieci w wieku 7-10 lat są zdolne do „przełamania” przewagi ucha prawego w testach rozdzielnousznych $\mathrm{z}$ użyciem sylab po ukierunkowaniu uwagi na ucho lewe. W wieku 11-12 lat różnica pomiędzy wynikiem z prawego i lewego ucha osiąga wartość zbliżoną do różnicy obserwowanej u osób dorosłych [35]. W badaniach Bellis [38] wielkość różnicy pomiędzy uchem prawym i lewym u dzieci 6-letnich wynosiła ok. 15\%, natomiast u dzieci 11-letnich osiągnęła wartość podobną do wyników osób dorosłych i wynosiła ok. 2\% [38]. Większe różnice pomiędzy wynikami obojga uszu u młodszych dzieci potwierdzają, że umiejętności słuchania rozdzielnousznego wzrastają wraz z wiekiem, co związane jest $\mathrm{z}$ dojrzewaniem układu słuchowego $[2,36]$.

W celu oceny powtarzalności i wiarygodności wyników u każdego dziecka badania wykonano trzykrotnie. Nie wykazano tendencji do poprawy wyników w kolejnym badaniu, niezależnie od grupy wiekowej i procedury badania. We wszystkich grupach wiekowych badania odznaczały się dużą powtarzalnością, bez względu na uzyskany odsetek prawidłowych odpowiedzi.

Testy słyszenia rozdzielnousznego są powszechnie stosowane w diagnozie zaburzeń przetwarzania słuchowego. Jak podają badania, są one czułe na uszkodzenia ośrodkowych części układu słuchowego (m.in. pnia mózgu i kory słuchowej) $[17,29]$. W badaniach Yathiraj i wsp. [30] wykazano, że około $65 \%$ dzieci z grupy ryzyka APD miało zaburzenia integracji i separacji słuchowej. Iliadou i wsp. [31] wykazali, że dzieci z APD osiągają słabsze wyniki niż dzieci z grupy kontrolnej. $Z$ kolei w badaniach Bellis i wsp.[38] w grupie dzieci z APD zaobserwowano występowanie znacznie większych asymetrii międzyusznych niż w grupie dzieci zdrowych.

Na podstawie przeprowadzonych analiz jednoznacznie można stwierdzić, że wiek w sposób istotny wpływa na wyniki rozdzielnousznego testu liczbowego. Dzieci w wieku około 11-12 lat osiągają wyniki zbliżone do wyników osób dorosłych, natomiast u młodszych dzieci obserwuje się znacznie niższy odsetek prawidłowych odpowiedzi. Uzyskane wyniki wskazują na konieczność zwrócenia szczególnej uwagi na ten czynnik podczas badania oraz interpretacji wyników testów rozdzielnousznych. Poznanie zależności pomiędzy wiekiem, uwagą i badanym uchem a wynikami testów rozdzielnousznych pozwala na opracowanie kryteriów diagnostycznych zaburzeń integracji i separacji słuchowej dla poszczególnych grup wiekowych.

\section{Piśmiennictwo:}

1. Hugdahl K. Fifty years of dichotic listening research - still going and going and... Brain Cogn, 2011; 76: 211-3.

2. Moncrieff DW, Wilson RH. Recognition of randomly presented one-, two-, and three-pair dichotic digits by children and young adults. J Am Acad Audiol, 2009; 20: 58-70.

3. Westerhausen R, Hugdahl $\mathrm{K}$. The corpus callosum in dichotic listening studies of hemispheric asymmetry: A review of clinical and experimental evidence. Neurosci Biobehav Rev, 2008; 32: 1044-54.

4. Kurkowski ZM. Lateralizacja słuchowa a zaburzenia komunikacji językowej. Audiofonologia, 2002; XXI: 179-86.

5. Jancke L, Buchanan TW, Lutz K, Shah NJ. Focused and nonfocused attention in verbal and emotional dichotic listening: An FMRI study. Brain Lang, 2001; 78: 349-63.

6. Kimura D. Functional asymmetry of the brain in dichotic listening. Cortex, 1967; 3(2): 163-78.

7. Kinsbourne M. The cerebral basis of lateral asymmetries in attention. Acta Psychol (Amst), 1970; 33: 193-201.

8. Jung P, Baumgartner U, Bauermann T, Magerl W, Gawehn J, Stoeter P, Treede RD. Asymmetry in the human primary somatosensory cortex and handedness. Neuroimage, 2003; 19(3): 913-23.
9. Hugdahl K, Bronnick K, Kyllinsbaek S, Law I, Gade A, Paulson $\mathrm{OB}$. Brain activation during dichotic presentations of consonant-vowel and musical instrument stimuli: a 15O-PET study. Neuropsychologia, 1999; 37(4): 431-40.

10. Van den Noort M, Specht K, Rimol LM, Ersland L, Higdahl K. A new verbal reports fMRI dichotic listening paradigm for studies of hemispheric asymmetry. Neuroimage, 2008; 40: 902-11.

11. Jancke L, Specht K, Shah J, Hugdahl K. Focused attention in a simple dichotic listening task: an fMRI experiment. Brain Res Cogn Brain Res, 2003; 16: 257-66.

12. Kurkowski ZM. Lateralizacja słyszenia a implanty ślimakowe. Audiofonologia, 1996; IX: 107-10.

13. Zenker F, Mora Espino R, Marro Cosialls S i wsp. The effect of age over the dichotic digit test. $8^{\text {th }}$ EFAS Congress, $10^{\text {th }}$ Congress of the German Society of Audiology, 2007.

14. Vanniasegaram I, Cohen M, Rosen S. Evaluation of selected auditory tests in school-age children suspected of auditory processing disorders. Ear Hear, 2004; 25(6): 586-97.

15. Berlin CI, Hughes LF, Lowe-Bell SS, Berlin HL. Dichotic right ear advantage in children 5 to 13. Cortex, 1973; 9(4): 394-402.

16. Geffen G. The development of the right ear advantage in dichotic listening with focused attention. Cortex, 1978; 14(2): 169-77. 
17. Musiek FE, Chermak GD, Weihing J, Zappulla M, Nagle S. Diagnostic accuracy of established Central Auditory Test Batteries in patients with documented brain lesions. J Am Acad Audiol, 2011; 22: 342-58.

18. Chi JG, Dooling EC, Gilles FH. Left-right asymmetries of the temporal speech areas of the human fetus. Arch Neurol, 1977; 34: $346-8$

19. Dehaene-Lambertz G, Dehaene S, Hertz-Pannier L. Functional neuroimaging of speech perception in infants. Science, 2002; 298: 2013-5.

20. Kuhl PK, Stevens E, Hayashi A, Deguchi T, Kiritani S, Iverson P. Infants show a facilitation effect for native language phonetic perception between 6 and 12 months. Dev Sci, 2006; 9: $13-21$.

21. Ahmad Z, Balsamo LM, Sachs BC, Xu B, Gaillard WD. Auditory comprehension of language in young children: neural networks identified with fMRI. Neurology, 2003; 60: 1598-605.

22. Balsamo LM, Xu B, Grandin CB, Petrella JR, Braniecki SH i wsp. A functional magnetic resonance imaging study of left hemisphere language dominance in children. Arch Neurol, 2002; 59: 1168-74.

23. Blumenfeld HK, Booth JR, Burman DD: Differential prefrontal-temporal neural correlates of semantic processing in children. Brain Lang, 2006; 99: 226-35.

24. Bryden MP, Munhall K, Allard F. Attentional biases and right ear effect in dichotic listening. Brain Lang, 1983; 18: 236-48.

25. Knecht S, Drager B, Deppe M, Bobe L, Lohmann H, Foel A i wsp. Hendedness and hemispheric language dominance in healthy humans. Brain, 2000; 123: 2512-8.

26. Obrębowski A. Uwagi do ośrodkowych zaburzeń mowy. Otorynolaryngologia, 2005; 4(4): 169-76.

27. Foundas AL, Corey DM, Hurley MM, Heilman KM. Verbal dichotic listening in right and left-handed adults: Laterality effects of directed attention. Cortex, 2006; 42: 79-86.

28. Gadea M, Gomez C, Espert R. Test-Retest performance for the consonant-vowel dichotic listening test with and without attentional manipulations. J Clin Exp Neuropsychol, 2000; 22(6): 793-803.

29. Goodglass H. Binaural digit presentation and early lateral brain damage. Cortex, 1967; 3(3): 295-306.
30. Yathiraj A, Maggu AR. Screening Test for Auditory Processing (STAP): a preliminary report. J Am Acad Audiol, 2013; 24(9): $867-78$.

31. Iliadou V, Kaprinis S, Kandylis D, Kaprinis GS. Hemispheric laterality assessment with dichotic digits testing in dyslexia and auditory processing disorder. Int J Audiol, 2010; 49, 247-52.

32. Lau CA. Dichotic Listening Training and CAPDOTS, a publication of The Listening Academy, Inc., 2014.

33. Dajos K, Piłka A, Senderski A, Kochanek K, Skarżyński H. Wyniki testów ośrodkowych funkcji słuchowych u dzieci i młodzieży w wieku szkolnym. Otorynolaryngologia, 2013; 12(2): 121-8.

34. Ingram D, Krishna G. Dichotic CV test - Revised normative data for children. Unpublished independent project submitted as a part of completion of Masters degree. Retrieved from: http://203.129.241.86:8080/digitallibrary/HomeAtoZ.do?alphabet $=$ DerecordPage $=10 \mho$ currentPage $=1,2001$

35. Mukari SZ, Keith RW, Tharpe AM, Johnson CD. Development and standarization of single and double dichotic digit tests in the Malay language. Int J Audiol, 2006; 45: 344-52.

36. Moncrieff DW. Dichotic listening in children: Age-related changes in direction and magnitude of ear advantage. Brain Cogn, 2011; 76(2): 316-22.

37. Lamm O, Epstein R. Dichotic listening in children: the reflection of verbal and attentional changes with age. J Exp Child Psychol, 1997; 65: 25-42.

38. Bellis TJ, Billiet C, Ross J. Hemispheric lateralization of bilaterally presents homologous visual and auditory stimuli in normal adults, normal children, and children with central auditory dysfunction. Brain Cogn, 2008; 66: 280-9.

39. Romero-Diaz A, Penaloza-Lopez Y, Garcia-Pedroza F, Perez SJ, Castro Camacho W. Central auditory processes evaluated with psychoacoustic tests in normal children. Acta Otorrinolaringol Esp, 2011; 62(6): 418-24.

40. Norrelgen F, Lilja A, Ingvar M, Gisselgård J, Fransson P. Language lateralization in children aged 10 to 11 years: a combined fMRI and dichotic listening study. PLOS One, 2012; 7(12), e51872, 1-11.

41. Hiscock M, Beckie JL. Overcoming the right ear advantage: a study of focused attention in children. Journal of Clin Exp Neuropsychol, 1993; 15(5), 754-72. 